\title{
THE ROLE OF UNION STRATEGIES IN NLRB CERTIFICATION ELECTIONS
}

\author{
KATE BRONFENBRENNER*
}

\begin{abstract}
Analyzing 1986-87 data from 261 NLRB certification election campaigns, the author finds that union tactic variables explain more of the variance in election outcomes than any other group of variables, including employer tactics, bargaining unit demographics, organizer background, election background, employer characteristics, and election environment. The results suggest that unions can significantly improve the probability of winning an election by using a rank-and-file intensive organizing strategy. This strategy includes a reliance on person-toperson contact; an emphasis on union democracy and representative participation; the building of support for the first contract during the organizing drive; the use of escalating pressure tactics; and an emphasis on dignity, justice, and fairness rather than on bread-and-butter issues.
\end{abstract}

$\mathbf{T}$ he 1980 s was a decade of crisis for the American labor movement marked by plant closings, the increasing use of permanent striker replacements, heightened international competition, and devastating organizing defeats. Yet in this period of crisis there were also several signs of a possible resurgence in union organizing success. Over ten thousand janitors won union recognition in Los Angeles; thousands of clerical workers were organized at major universities across the country; the Amalgamated Clothing and Textile Workers Union (ACTWU) was able to win a

* Kate Bronfenbrenner is the Director of Labor Education Research at the New York State School of Industrial and Labor Relations, Cornell University. Financial support for this study was provided by the AFL-CIO Department of Organizing and the Institute for Collective Bargaining at the School of Industrial and Labor Relations at Cornell University. string of major manufacturing victories in the Deep South; and a coalition of unions led by the Service Employees International Union (SEIU) and 1199 won representation rights at the fiercely anti-union Beverly Enterprises, a national for-profit nursing home chain.

In the 1990s many local and national unions increased their commitment to organizing by shifting both financial and staff resources from servicing existing members

The statistical analyses described in this paper were performed using the SYSTAT statistical package (Version 4.0). Requests for details of computer programs used to generate the results and other pertinent information regarding the data and measures used should be addressed to Kate Bronfenbrenner, 207 Extension Building, New York State School of Industrial and Labor Relations, Cornell University, Ithaca, NY 14853. Proprietary arrangements with the AFL-CIO preclude the sharing of the data.

Industrial and Labor Relations Review, Vol. 50, No. 2 (January 1997). (c) by Cornell University. $0019-7939 / 97 / 5002 \$ 01.00$ 
to external organizing. ${ }^{1}$ In 1995, newly elected AFL-CIO leaders committed 20 million dollars to "organize at a pace and scale that is unprecedented" (Sweeney, Trumka, and Chavez-Thompson 1995:5).

Much previous industrial relations research has analyzed the factors contributing to the labor movement's declining organizing success. Studies have examined how organizing outcomes are affected by the political, economic, and legal climate; individual workers' attitudes toward their work and the labor movement; employer characteristics and tactics; and bargaining unit demographics.

Few of the previous studies, however, have effectively examined the actual process of a union organizing campaign and the influence of union practices and strategies on certification election outcomes. Most likely, these factors have been ignored because of over-reliance on NLRB data, which are limited to information on employer characteristics and election background. Data on union characteristics and tactics are considerably more difficult to obtain, yet they are essential if we are to fully understand the determinants of union election outcomes.

In 1988, in cooperation with the Organizing Department of the AFL-CIO, I collected a novel data set to analyze the factors contributing to union success or failure in certification election campaigns. ${ }^{2}$ The primary aim of the research was to identify which, if any, union strategies affected union certification election outcomes, controlling for the influence of election background, organizing climate, bargaining unit demographics, and employer characteristics and tactics. In this paper I analyze the

'AFL-CIO National Organizing Committee Meeting, March 9, 1995, as well as individual interviews with organizers, local officers, and organizing directors from SEIU, IBT, AFSCME, and UNITE.

${ }^{2}$ The study examined both the organizing and the first contract process in the private sector. For information on the first contract study, refer to Bronfenbrenner (1993); for information on public sector organizing, see Bronfenbrenner and Juravich $(1995,1995 \mathrm{a}$, and $1995 \mathrm{~b})$. results of that research and discuss the implications for unions.

\section{Theoretical Framework}

Most previous union organizing research has been based on a unidirectional model framing the union certification election outcome as a function of workers' propensity to vote for the union, as influenced by contextual variables (such as election type or economic climate) and employer characteristics and tactics (see, for example, Cooke 1983). ${ }^{3}$ In a small number of studies, union actions have also been included in equations predicting union organizing success (Reed 1989; Maranto and Fiorito 1987). However, as Lawler (1990) argued, most of these studies are based on the assumption that union and employer actions only indirectly affect election outcomes by moderating contextual influences on the individual's propensity to vote for the union. They tend to ignore how employers and unions adjust their strategies in response to or in expectation of each other's behavior, as well as the ability of union and management behavior to strategically affect the broader organizing climate.

As Hurd and McElvaine (1988), Lynn and Brister (1989), and Green and Tilly (1987) found in their interviews with union organizers, many employer and union organizing strategists specifically tailor their tactics to conform with bargaining unit demographics and the particular economic, political, and social environment in which each campaign takes place. Unions and employers also may adjust their strategies in preparation for or in reaction to tactics being used by the other side. In addition, some union and employer tactics directly affect the election outcome without being filtered through the individual voter, such as contracting out work or union public pressure campaigns against the NLRB.

${ }^{3}$ For an in-depth review of the research literature on the determinants of certification election outcomes, see Bronfenbrenner (1993), Lawler (1990), Wheeler and McClendon (1991), and Fiorito and Greer (1982). 


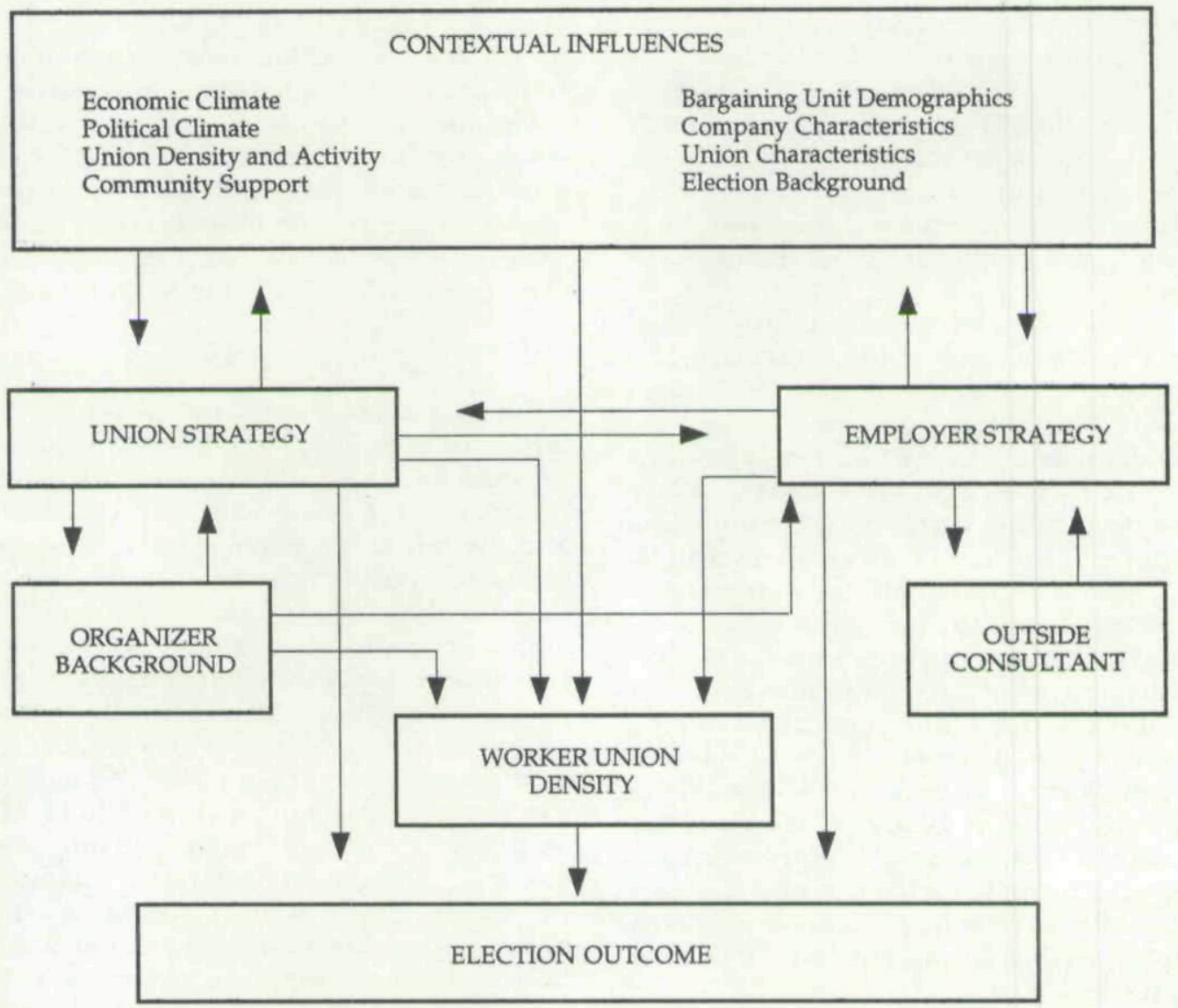

Figure 1. Theoretical Model of the Certification Election Process.

Informed by Lawler's strategic choice model of unionization, this study uses a theoretical model positing that union certification election outcomes are a function of interacting elements including the contextual background, union and employer strategies, organizer background, the use of a management consultant, and workers' propensity to unionize. As diagrammed in Figure 1, this model, like earlier models of unionization outcomes, proposes that at the center of the certification election process are the individual union voters, who come into the election with some predisposition for or against unions. But a combination of contextual factors and union and employer characteristics and strategies also affects election outcomes. These factors indirectly moderate the individuals' propensity to vote for the union, they interact with other employer and union factors, and they directly affect union and employer strategies, which in turn affect the election outcome. ${ }^{4}$

In the model presented here, contextual factors such as the economic and political

\footnotetext{
${ }^{4}$ Although strategies themselves are not easily observable and therefore are difficult to operationalize and test, the tactics through which strategies are implemented can be operationalized and tested.
} 
climate, election type, company profitability, unionization history, and the individual's race and gender are all hypothesized to directly influence a worker's propensity to vote for the union. In addition, these contextual factors indirectly affect a voter's decision because they influence unions' and employers' organizing strategies.

Unions and employers can also moderate the impact of contextual variables through tactics such as legal actions to get a more favorable bargaining unit or election date, or the union can target its organizing efforts to gain more favorable bargaining unit demographics. Unions and employers also directly affect how individual voters perceive union effects on their work or pay situation, and unions and employers can alter workers' perceptions of the economic and social risks of unionization. For example, some unions use rank-and-file volunteers from previously organized units to visit workers at home to educate them about the benefits of unionization and "inoculate" them against the employer campaign. Similarly, employers may use captive audience meetings to convince their employees that unions are a threat to their job security.

Union and employer strategies also can be directed at each other. Some are proactive, such as the union running a public media campaign to embarrass the employer into staging a less aggressive campaign. Others are reactive, such as the employer setting up an employee involvement committee to undercut union charges that the employer is not listening to workers' concerns.

This model also includes direct action strategies by the union or the employer that affect election outcomes without being filtered through the employee's propensity to vote for the union. For example, an employer may stop an election by contracting out bargaining unit work, or the union may circumvent the NLRB by having other unionized employees bargain for recognition based on a majority card check of the unorganized unit.

Finally, this model includes separate vari- ables for organizer background and employer use of a management consultant. Both organizers and consultants can develop and implement employer or union strategies. In addition, through their background, personality, and behavior, these individuals can affect workers' attitudes about the union and the employer and their propensity to vote for the union.

\section{Hypotheses}

The hypotheses tested in this study were informed by case studies of successful union campaigns, as well as discussions with organizers, labor leaders, and labor educators and my ten years' experience as a union organizer and negotiator. Case evidence suggests that union success in organizing depends on running campaigns with a focus on representative leadership, personal contact, dignity and justice, and building an active union presence in the workplace from the very beginning of the campaign. ${ }^{5}$ These campaign tactics make up what I and others refer to as a "rank-and-file intensive strategy." A rank-and-file strategy increases the likelihood of union electoral success because it generates the worker participation and commitment necessary to withstand aggressive employer anti-union campaigns (which are now commonplace) and to counteract any anti-union aspects of the economic, political, and legal climate.

A rank-and-file intensive organizing strategy has six basic components. Below, I describe the components and state hypotheses for each.

Component 1. Reliance on a slow, underground, person-to-person campaign using housecalls, small group meetings, and preunion associations to develop leadership and union commitment, and prepare workers for employer anti-union strategies before the employer becomes aware of the campaign.

\footnotetext{
${ }^{5}$ See Green and Tilly (1987), Hurd (1988, 1989), Fetonte and Braden (1990), and Lynn and Brister (1989) for case studies that cite examples of these kinds of campaigns and campaign strategies.
} 
Hypothesis 1a: Percent signed cards $(+)$. The percent cards variable measures the degree of organizing the union engaged in prior to filing the election petition. I hypothesize that the greater the percentage of the bargaining unit the union signs up on cards before the election petition is filed, the greater the personal contact the union has made with individual workers and the greater the likelihood that the union has been able to educate workers about the union and inoculate them against the employer's anti-union campaign before that campaign is launched.

Hypothesis 1b: Number of small group meetings $(+)$. This variable assesses the number of small group meetings the union held in workers' homes or local gathering places during the campaign. I hypothesize that the number of small group meetings will be positively related to union election success because it is an indicator of the intensity of the union's efforts as well as the degree of personal contact the union made with bargaining unit members during the campaign.

Hypothesis 1c: Fifty percent or more of unit housecalled $(+)$. This variable is based on the percentage of the unit housecalled prior to the election. I hypothesize that unions will have more success when they housecall the majority of the unit because housecalling represents intensive personal contact. In their homes workers are able to frankly discuss their concerns and questions free from employer surveillance and intimidation and free from the time constraints inherent in workplace discussions. To housecall $50 \%$ or more of the unit, unions must track down the names and addresses of these workers. Thus this variable provides an im- portant measure of the energy, staff, and volunteer resources the union commits to organizing, and it also measures the degree of personal contact with the bargaining unit.

Hypothesis 1d: Number of union letters mailed $(-)$. This variable measures the number of letters mailed by the union to bargaining unit members during the organizing campaign. It is a proxy for a traditional organizing drive in which the emphasis is placed on gate leafletting and letters rather than personal contact. I hypothesize that the more letters the union mails out, the fewer are the resources available for a rank-andfile intensive campaign.

Component 2. A focus on active rank-andfile participation in and responsibility for the organizing campaign, including a large rank-and-file organizing committee representative of the different interest groups in the bargaining unit.
Hypothesis 2: Representative orga- nizing committee $(+)$. This vari- able captures how representative the in-plant organizing committee is of the bargaining unit as a whole. I hypothesize that unions using rep- resentative rank-and-file commit- tees will be more successful in cer- tification elections because they will be more in touch with the issues and concerns of the bargaining unit, they will have better access to workers in the workplace, and they will be able to demonstrate to the workers that they are a democratic and inclusive organization.

Component 3. A long-run campaign strategy that incorporates pressure for a first contract in the original organizing process.

Hypothesis 3a: Percent of unit that did contract survey $(+)$. This variable measures the percentage of the unit that completed a contract survey through personal contact with a committee member or a 
union staff member before the certification election. It does not include contract surveys distributed through the mail or gate leafletting, because those surveys can be completed without personal contact. I hypothesize that unions seeking information regarding the issues individual bargaining unit members want addressed in the first contract will be more able to build worker commitment to the union.

Hypothesis 3b: Bargaining committee established before the election $(+)$. As with the contract survey variable, I hypothesize that establishing a bargaining committee before the certification election builds worker confidence that the union is going to win the certification election and successfully bargain a first agreement, thereby increasing bargaining unit support for the union during the certification election campaign.

Component 4. Inside and outside pressure tactics to build worker commitment and compel the employer to run a fair campaign.

Hypothesis 4: Solidarity days used $(+)$. Solidarity days are union-designated days on which supporters are asked to wear union buttons, hats, t-shirts, arm bands, or other union insignia to build commitment among the membership and actively demonstrate union support and solidarity to the employer. I hypothesize that these actions aid the union's efforts by reinforcing commitment among pro-union workers and by helping to convince undecided voters that they can safely support the union. The public show of support also makes it more difficult for the employer to intimidate workers one-on-one and to argue that only a small group of troublemakers support the union's campaign.

Component 5. An emphasis during the organizing campaign on issues such as respect, dignity, fairness, and service quality that go beyond the traditional bread-andbutter issues of wages, fringes, benefits, and job security.

Hypothesis 5: Union used new issues $(+)$. This variable captures whether the union focused on issues such as dignity, fairness, and input into service and product quality rather than only traditional issues such as wages, benefits, working conditions, and job security. I hypothesize that unions will have greater success when they focus on these "new issues" than when they simply rely on traditional bread-and-butter issues during the campaign.

Component 6. An emphasis on developing a culture of organizing that permeates the union. This includes a serious commitment of staff and financial resources to organizing, the involvement of staff from the international union in local union organizing campaigns, and the use of rankand-file volunteers from already organized bargaining units.

Hypothesis 6a: Rank-and-file volunteers did housecalls $(+)$. This variable captures whether the union used rank-and-file volunteers from other organized workplaces to campaign among bargaining unit members. Organized workers from the same union can effectively carry the union's message during an organizing campaign.

Hypothesis 6b: Individual Union Variables: IBT (-), USWA (-), UAW $(+)$, SEIU (+), UFCW (+). I include the individual union variables in the model in an attempt to control for aspects of union culture and other union characteristics that have not been captured by the union tactic variables in the model. Unfortunately, including variables for all 29 unions would severely limit the degrees of freedom in the statistical analyses. Hence, I restricted the individual union vari- 
ables to the 5 unions in the sample that had at least 20 elections. These 5 unions (IBT, USWA, UAW, SEIU, and UFCW) cover over $50 \%$ of the elections in the sample.

A positive sign is hypothesized for SEIU and the UAW because these unions appear to have made a strong commitment to organizing as reflected in training, resources, and membership education. For the IBT and the USWA I hypothesize a negative sign, because when these elections took place in 1986-87, neither union had made organizing a strong priority. ${ }^{6}$ A negative sign is also hypothesized for the UFCW. Although that union has devoted large amounts of financial resources to organizing, some of the larger local unions appear to have failed to adapt their organizing strategy to meet the needs and concerns of the women and minority workers who dominate the retail food industry work force. In addition, the growing emphasis by the UFCW on circumventing the NLRB by using nonbargaining unit members to picket for recognition has made grassroots-level NLRB campaigns less of a priority for the union.

\section{Data}

The data used in this study include a survey conducted by the AFL-CIO of 189 union NLRB certification election campaigns in units of over 50 eligible voters that took place between July 1986 and June

\footnotetext{
${ }^{6}$ Both unions have had major changes in their organizing operations since the survey took place. With the election of Ron Carey, organizing has become one of the top priorities of the Teamsters, with the International taking over much of the organizing formally under the exclusive jurisdiction of the locals. In the last few years the USWA has launched a nationwide organizer training program for USWA staff and transferred new organizer recruitment and training decisions from the District directors to the AFL-CIO Organizing Institute.
}

1987 (AFL-CIO 1989). The original AFLCIO sample excluded or under-represented several major unions, especially those organizing in the service sector. For the final sample in this study, I corrected for these problems by adding a random sample of 72 HERE, SEIU, IBT, ACTWU, and HHCE 1199 campaigns to the AFL-CIO sample. With this addition, the combined sample is representative across unions, industries, regions, and unit types. A follow-up questionnaire was sent out to the participants in the AFL-CIO survey asking more detailed questions regarding organizer background, bargaining unit demographics, and tactics used to gain a first contract. ${ }^{7}$

The final sample is restricted to single union NLRB elections involving AFL-CIO affiliates in units of 50 or more eligible voters. ${ }^{8}$ Organizers from 29 different AFLCIO affiliates participated in the survey. The 261 elections in the sample cover slightly less than a third of the 961 AFL-CIO affiliate single union elections in units over 50 held during the sample period. In addition to the union tactic variables specified in the various hypotheses, the equations include as controls variables that measure the following: election background, election environment, company characteristics, unit demographics, organizer background, and company tactics. The definition, source, and hypothesized sign for each of these variables are provided in Table $1 .^{9}$

\footnotetext{
${ }^{7}$ When organizers were unable or unwilling to answer questions in the follow-up survey, the missing data were recorded in the following manner. For dummy variables measuring the existence of a characteristic or the use of a tactic, the variable was coded as 0 . For all continuous variables the variable was coded as the mean response of all other cases for that variable. The model was tested after eliminating all cases with any missing data, and the results were then stronger or the same for every variable that had statistically significant effects. Filling in the missing data, thus, does not appear to bias the results, and it allows more cases to be included in the sample.

${ }^{8}$ NLRB multi-union elections and elections involving non-AFL-CIO affiliates involved less than $1 \%$ of the total NLRB elections during this period.

${ }^{9}$ For an in-depth discussion of the rationale and hypothesized impact of each of these variables, see Bronfenbrenner (1993), pp. 245-61.
} 
ถั้

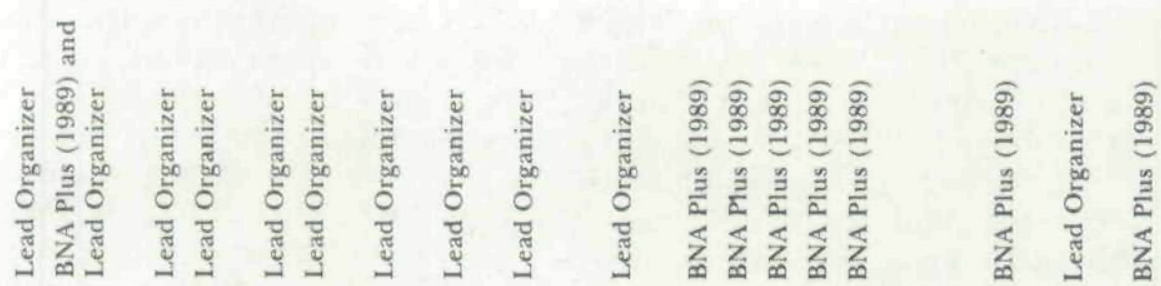

है
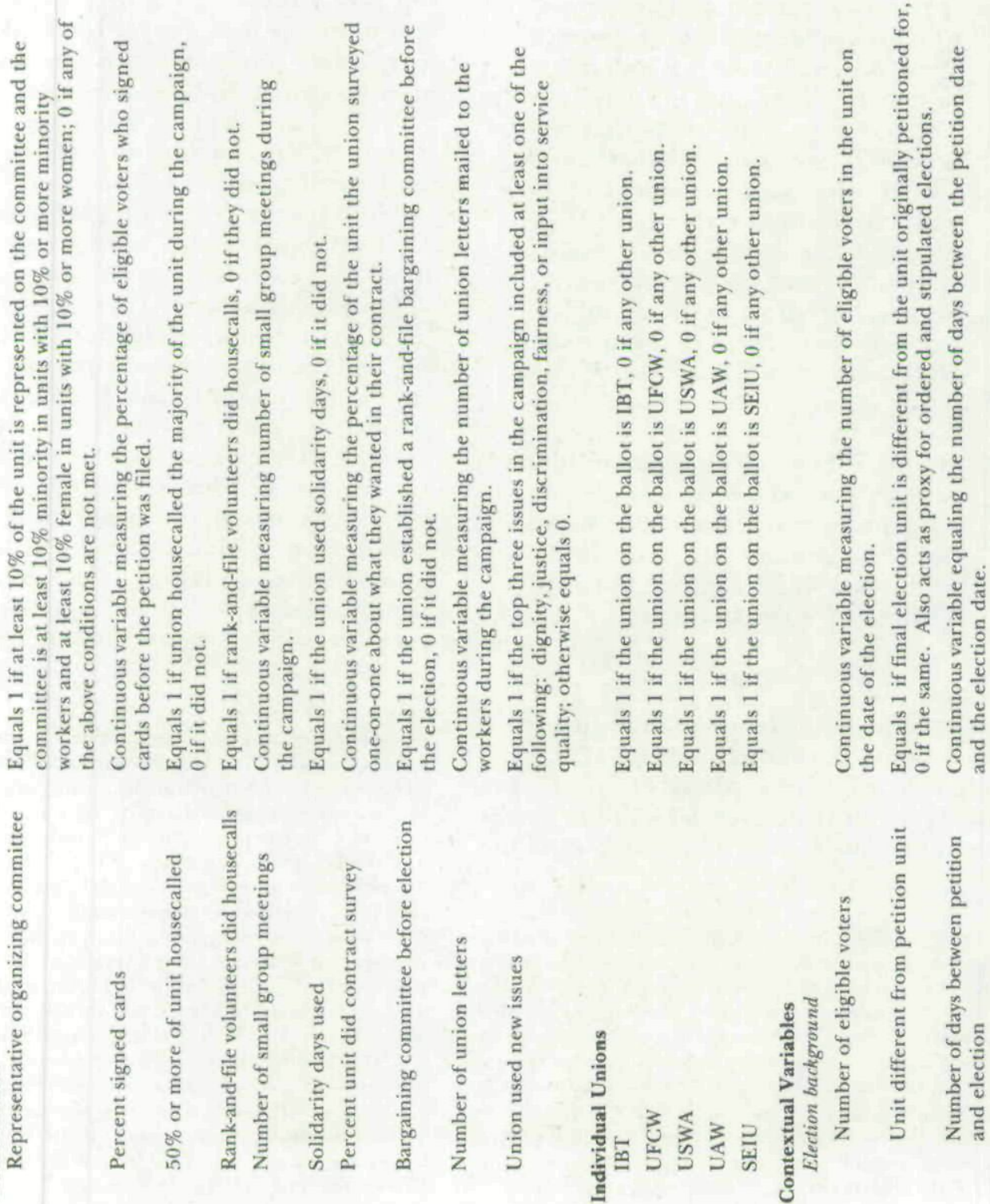


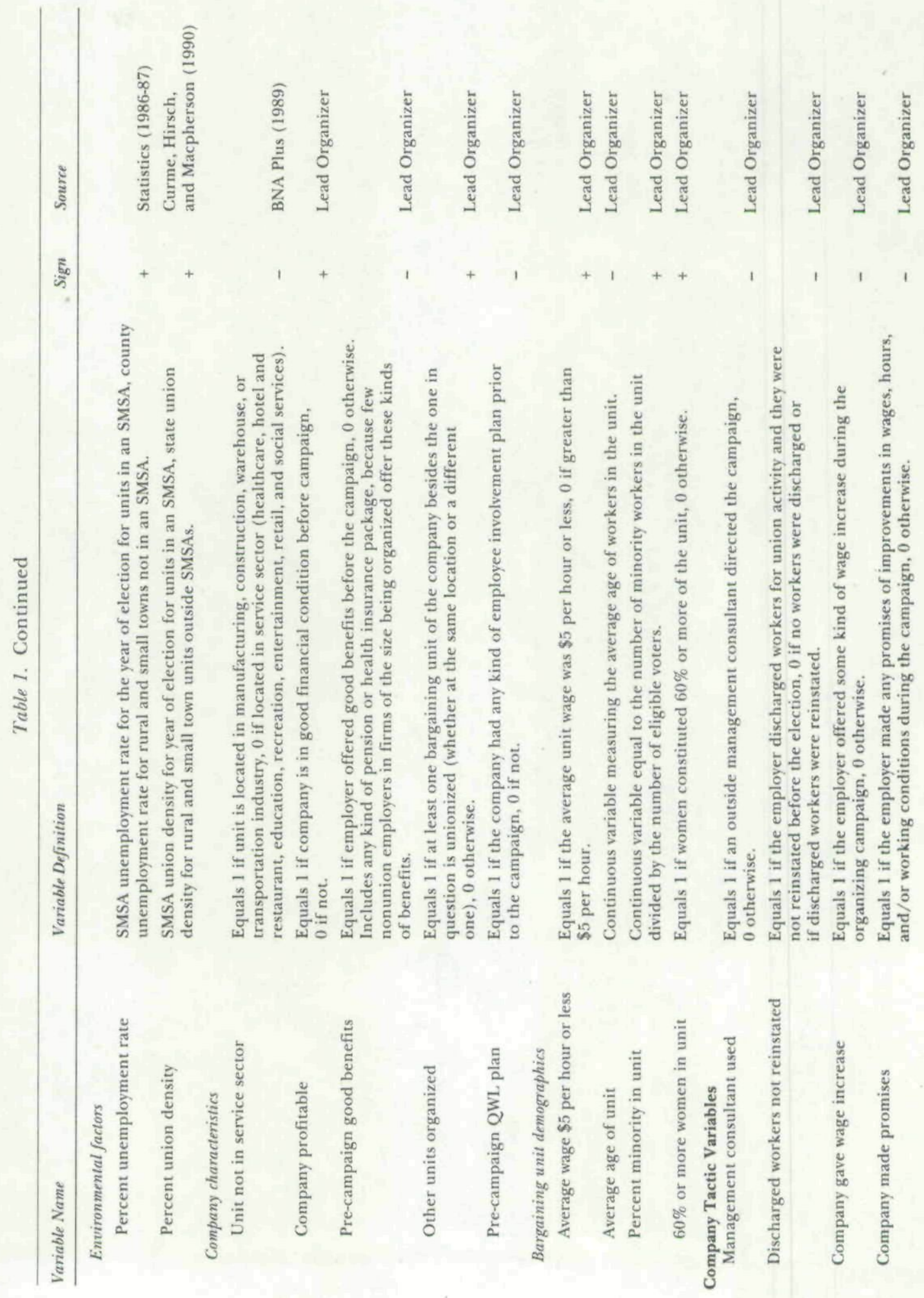




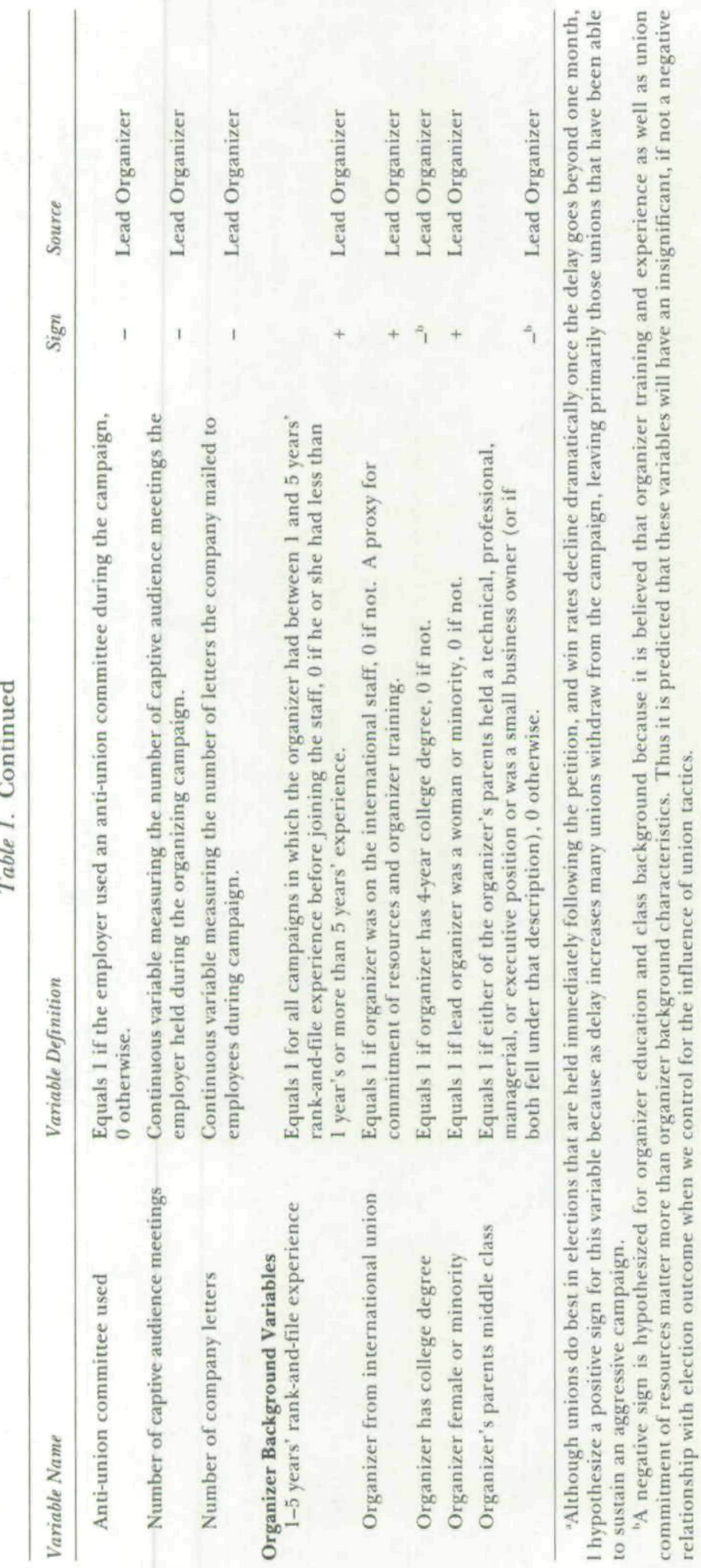




\section{Methods}

In order to compare the results of this study with the findings of other bargaining unit-level election studies, in this study I use as a dependent variable both the proportion of votes received by the union in the election (Equation 1) and a dichotomous win-lose variable (Equation 2) as dependent variables.

Because the percentage union vote is a bounded by zero and one, weighted least squares is the preferred multi-variate statistical method when the dependent variable is the proportion of votes received by the union (Maranto and Fiorito 1987; Reed 1989). It is also generally accepted that logit is the appropriate estimator for a binary dependent variable such as win-lose (Aldrich and Nelson 1984). Therefore, Equation 1 uses weighted least squares and measures the dependent variable as the log odds ratio of the percentage union vote or $\left.\ln \left[p_{i} / \gamma-p_{i}\right)\right]$, with each variable in the model weighted by the square root of the inverse of the variance, $\sqrt{\gamma /\left[N_{i} p_{i}(\gamma-p)\right]} \cdot{ }^{10}$

Equation 2 is estimated by a log-likelihood function in which the dichotomous dependent variable of union win $=1$ and union lose $=0$ is a function of $\gamma /[\gamma+$ $\exp (x \beta)]$, where $x$ is the vector of independent variables and $\beta$ is a vector of logit coefficients.

\section{Results and Discussion}

Overall, the two equations (WLS and logit) provide approximately equal explanatory power regarding factors contributing to union success in certification elections. As shown in Table 2, the WLS equation with the log odds ratio of the percentage union vote as the dependent variable is statistically significant at a level of less than .001, with an adjusted $\mathrm{R}$-squared of .438 and an $\mathrm{F}$

${ }^{10}$ As noted by Aldrich and Nelson (1984) and Maddala (1983), when each variable on both sides of the equation is weighted by the square root of the inverse of the variance, the dependent variable is no longer limited, and problems with heteroskedasticity are avoided. statistic of 5.807. The logit equation with the dummy dependent variable of $1=$ union win and $0=$ union lose is statistically significant at a level of less than .001 , with a McFadden's Rho-squared of .469 and a log likelihood ratio of 167.080 .

Perhaps the most important finding in this study is that the union tactic variables as a group explain a greater part of the variance in election outcome than any other elements of the certification election model. That is, not only do union tactics matter, but as a group they matter more than employer tactics, bargaining unit demographics, organizer background, or organizing climate.

The relative importance of union tactics is shown in Table 4, where each of the estimated equations is broken down into the different elements of the certification election model, including contextual variables, organizer background variables, management tactic variables, union tactic variables, and individual union variables. The contextual variables are broken down still further by election background, election environment, employer characteristics, and bargaining unit demographics. In Table 4, nine different WLS and logit equations were used to test portions of the model. In each equation the independent variables were limited to the variables for each element of the complete model. Thus one equation only included union tactics as independent variables, another only individual union variables, and the remaining equations included organizer background, management tactics, and contextual factors. The contextual factors variable was then further separated into its component parts, including variables measuring election background, election environment, company characteristics, and unit demographics. The $\mathrm{R}^{2}$ and, in the logit equations, the $\mathrm{Rho}^{2}$ for each of the equations can be compared both to the results for the other portions of the model and to the results for the complete model.

In the WLS equation, the adjusted Rsquared for union tactics (.276) was higher than the adjusted R-squared for any of the other elements of the model. In the logit 
Table 2. Descriptive Statistics for the Certification Election Model.

\begin{tabular}{|c|c|c|c|c|}
\hline Independent Variable & $\begin{array}{l}\text { Hypothesized } \\
\text { Sign }\end{array}$ & $\begin{array}{l}\text { Sample Mean } \\
\text { or Proportion }\end{array}$ & $\begin{array}{c}\text { Percent Win } \\
\text { Rate' }\end{array}$ & $\begin{array}{c}\text { Variable } \\
\text { Range }\end{array}$ \\
\hline \multicolumn{5}{|l|}{ Union Tactics } \\
\hline Representative organizing committee & + & .23 & $.62(.36)$ & 0 or 1 \\
\hline Percent signed cards & + & .60 & NA & $0-1.78$ \\
\hline $50 \%$ or more of unit housecalled & + & .28 & $.61(.35)$ & 0 or 1 \\
\hline Rank-and-file volunteers did housecalls & + & .18 & $.52(.40)$ & 0 or 1 \\
\hline Number of small group meetings & + & 5.26 & NA & $0-100$ \\
\hline Solidarity days used & + & .12 & $.53(.41)$ & 0 or 1 \\
\hline Percent unit did contract survey & + & 32.19 & NA & $0-100$ \\
\hline Bargaining committee before election & + & .15 & $.64(.39)$ & 0 or 1 \\
\hline Number of union letters & - & 4.14 & NA & $0-50$ \\
\hline Union used new issues & + & .27 & $.56(.37)$ & 0 or 1 \\
\hline \multicolumn{5}{|l|}{ Individual Unions } \\
\hline IBT & - & .14 & $.28(.45)$ & 0 or 1 \\
\hline UFCW & - & .12 & $.50(.41)$ & 0 or 1 \\
\hline USWA & - & .12 & $.23(.45)$ & 0 or 1 \\
\hline UAW & + & .11 & $.46(.42)$ & 0 or 1 \\
\hline SEIU & + & .09 & $.61(.45)$ & 0 or 1 \\
\hline \multicolumn{5}{|l|}{ Contextual Factors } \\
\hline \multicolumn{5}{|l|}{ Election background } \\
\hline Number of eligible voters & - & 138.00 & NA & $46-650$ \\
\hline Unit different from petition unit & - & .22 & $.22(.47)$ & 0 or 1 \\
\hline Number of days between petition & & & & \\
\hline and election & + & 79.25 & NA & $2-881$ \\
\hline \multicolumn{5}{|l|}{ Environmental factors } \\
\hline Percent unemployment rate & + & 7.16 & NA & $2.1-17.7$ \\
\hline Percent union density & + & 20.79 & NA & $5.8-42.9$ \\
\hline \multicolumn{5}{|l|}{ Company characteristics } \\
\hline Unit in manufacturing sector & - & .66 & $.39(.47)$ & 0 or 1 \\
\hline Company profitable & - & .84 & $.40(.53)$ & 0 or 1 \\
\hline Pre-campaign benefits good & - & .26 & $.37(.44)$ & 0 or 1 \\
\hline Pre-campaign QWL plan & - & .07 & $.22(.44)$ & 0 or 1 \\
\hline Other units organized & + & .46 & $.49(.38)$ & 0 or 1 \\
\hline \multicolumn{5}{|l|}{ Bargaining unit demographics } \\
\hline Average wage $\$ 5$ per hour or less & + & .41 & $.56(.33)$ & 0 or 1 \\
\hline Average age of unit & - & 32.77 & NA & $19-55$ \\
\hline $60 \%$ or more women in unit & + & .39 & $.53(.36)$ & 0 or 1 \\
\hline Percent minority in unit & + & .28 & NA & $0-1$ \\
\hline \multicolumn{5}{|l|}{ Organizer Background } \\
\hline 1-5 years rank-and-file experience & + & .16 & $.67(.38)$ & 0 or 1 \\
\hline Organizer from international union & + & .47 & $.43(.42)$ & 0 or 1 \\
\hline Organizer has college degree & - & .26 & $.42(.43)$ & 0 or 1 \\
\hline Organizer female or minority & + & .25 & $.56(.38)$ & 0 or 1 \\
\hline Organizer's parents middle class & - & .17 & $.36(.44)$ & 0 or 1 \\
\hline \multicolumn{5}{|l|}{ Employer Tactics } \\
\hline Management consultant used & - & .71 & $.40(.50)$ & 0 or 1 \\
\hline Discharged workers not reinstated & - & .18 & $.37(.44)$ & 0 or 1 \\
\hline Company gave wage increase & - & .30 & $.32(.47)$ & 0 or 1 \\
\hline Company made promises & - & .56 & $.34(.54)$ & 0 or 1 \\
\hline Anti-union committee used & - & .42 & $.37(.46)$ & 0 or 1 \\
\hline Number of captive audience meetings & - & 5.50 & NA & $0-200$ \\
\hline Number of company letters & - & 4.47 & NA & $0-50$ \\
\hline
\end{tabular}

"Percent win rate is listed for all dummy variables when the variable $=1$ (win rate for variable $=0$ in parentheses).

equation, the contextual variable group has a slightly higher Rho-squared (.187) than does union tactics (.169); but with that one exception, the Rho-squared for union tactics exceeds that for all the other elements, and union tactics continues to explain more then twice as much of the variance as any of the subcategories of contextual variables, including election background, election environment, employer 
Table 3. Determinants of Election Outcomes. WLS and Logit Estimations of Election Outcome Models for Two Dependent Variables: Log Odds Ratio of Percent Union Vote and Win-Lose. (Standard Errors in Parentheses)

\begin{tabular}{|c|c|c|c|c|c|}
\hline \multirow[b]{2}{*}{ Independent Variable } & \multicolumn{2}{|c|}{$\begin{array}{c}\text { Weighted Least Squares } \\
\text { Log (\% Union Vote) }\end{array}$} & \multicolumn{3}{|c|}{ Logil Win-Lose } \\
\hline & \multicolumn{2}{|c|}{ Standardized Coefficient } & \multicolumn{2}{|c|}{ Coefficient } & Partial Derivative \\
\hline \multicolumn{6}{|l|}{ Union Tactics } \\
\hline Representative organizing committee & $0.108^{* *}$ & $(0.101)$ & 0.189 & $(0.562)$ & 0.022 \\
\hline Percent signed cards & $0.716^{* * *}$ & $(0.237)$ & $4.085^{* * * *}$ & $(1.420)$ & 0.475 \\
\hline $50 \%$ or more of unit housecalled & -0.021 & $(0.092)$ & $0.682^{*}$ & $(0.495)$ & 0.079 \\
\hline Rank-and-file volunteers did housecalls & 0.010 & $(0.101)$ & 0.548 & $(0.517)$ & 0.064 \\
\hline Number of small group meetings & $0.115^{* *}$ & $(0.004)$ & 0.020 & $(0.016)$ & 0.002 \\
\hline Solidarity days used & $0.189^{* * *}$ & $(0.122)$ & $1.213^{*}$ & $(0.810)$ & 0.141 \\
\hline Percent unit did contract survey & 0.079 & $(0.001)$ & $0.011 * *$ & $(0.006)$ & 0.001 \\
\hline Bargaining committee before election & $0.162 * * *$ & $(0.103)$ & $1.173 * *$ & $(0.633)$ & 0.136 \\
\hline Number of union letters & $-0.205^{* * *}$ & $(0.009)$ & -0.051 & $(0.059)$ & -0.006 \\
\hline Union used new issues & $0.188^{* * *}$ & $(0.082)$ & $1.265^{* * *}$ & $(0.477)$ & 0.147 \\
\hline \multicolumn{6}{|l|}{ Individual Unions } \\
\hline SEIU & $0.100^{*}$ & $(0.149)$ & 0.442 & $(0.940)$ & 0.051 \\
\hline UAW & $0.084^{*}$ & $(0.131)$ & 0.117 & $(0.669)$ & 0.014 \\
\hline UFCW & 0.030 & $(0.134)$ & -0.401 & $(0.641)$ & -0.047 \\
\hline IBT & $-0.190^{* * *}$ & $(0.142)$ & $-1.308^{*}$ & $(0.819)$ & -0.152 \\
\hline USWA & -0.062 & $(0.120)$ & -1.579 & $(0.706)$ & -0.184 \\
\hline \multirow{2}{*}{\multicolumn{6}{|c|}{ Contextual Factors }} \\
\hline & & & & & \\
\hline Number of eligible voters & -0.085 & $(0.000)$ & $-0.007 * * *$ & $(0.003)$ & -0.001 \\
\hline Unit different from petition unit & -0.081 & $(0.087)$ & $-1.279 * *$ & $(0.556)$ & -0.149 \\
\hline $\begin{array}{l}\text { Number of days between petition } \\
\text { and election }\end{array}$ & $0.214 * * *$ & $(0.000)$ & $0.007 * * *$ & $(0.003)$ & 0.001 \\
\hline \multicolumn{6}{|l|}{ Environmental factors } \\
\hline Percent unemployment rate & 0.187 & $(0.014)$ & $0.174 * *$ & $(0.082)$ & 0.020 \\
\hline Percent union density & -0.078 & $(0.006)$ & $0.066^{* * *}$ & $(0.033)$ & 0.008 \\
\hline \multicolumn{6}{|l|}{ Company characteristics } \\
\hline Unit in manufacturing sector & 0.006 & $(0.099)$ & 0.289 & $(0.548)$ & 0.034 \\
\hline Company profitable & $-0.314^{* * *}$ & $(0.096)$ & $-0.931 * *$ & $(0.545)$ & -0.108 \\
\hline Pre-campaign benefits good & -0.008 & $(0.087)$ & 0.772 & $(0.480)$ & 0.090 \\
\hline Pre-campaign QWL plan & -0.068 & $(0.135)$ & $-1.929 * *$ & $(0.918)$ & -0.224 \\
\hline Other units organized & $0.122 * *$ & $(0.077)$ & $0.945^{* * *}$ & $(0.453)$ & 0.110 \\
\hline \multicolumn{6}{|l|}{ Bargaining unit demographics } \\
\hline Average wage $\$ 5$ per hour or less & 0.056 & $(0.088)$ & $0.886 * *$ & $(0.500)$ & 0.103 \\
\hline Average age of unit & $-0.620^{* *}$ & $(0.006)$ & $-0.082 * * *$ & $(0.035)$ & -0.010 \\
\hline $60 \%$ or more women in unit & 0.012 & $(0.085)$ & $0.879 * *$ & $(0.507)$ & 0.102 \\
\hline Percent minority in unit & $0.137 * *$ & $(0.127)$ & $2.334^{* * * *}$ & $(0.706)$. & 0.271 \\
\hline \multicolumn{6}{|l|}{ Organizer Background } \\
\hline 1-5 years' rank-and-file experience & 0.051 & $(0.107)$ & $1.146 * *$ & $(0.622)$ & 0.133 \\
\hline Organizer from international union & -0.117 & (0.083) & $0.831 * *$ & $(0.481)$ & 0.197 \\
\hline Organizer has college degree & $-0.241^{* * *}$ & $(0.095)$ & -1.172 & $(0.607)$ & -0.136 \\
\hline Organizer female or minority & 0.072 & $(0.086)$ & 0.586 & $(0.478)$ & 0.068 \\
\hline Organizer's parents middle class & -0.019 & $(0.103)$ & -0.491 & $(0.584)$ & -0.057 \\
\hline \multicolumn{6}{|l|}{ Employer Tactics } \\
\hline Management consultant used & -0.071 & $(0.093)$ & -0.246 & $(0.494)$ & -0.029 \\
\hline Discharged workers not reinstated & -0.038 & $(0.100)$ & -0.689 & $(0.623)$ & -0.080 \\
\hline Company gave wage increase & $-0.145^{* *}$ & $(0.082)$ & $-0.777^{*}$ & $(0.500)$ & -0.090 \\
\hline Company made promises & -0.058 & $(0.076)$ & $-1.154 * * *$ & $(0.430)$ & -0.134 \\
\hline Anti-union committee used & $-0.207 * * *$ & $(0.073)$ & -0.012 & $(0.442)$ & -0.001 \\
\hline Number of captive audience meetings & $-0.126^{* *}$ & $(0.003)$ & $-0.124 * * *$ & $(0.041)$ & -0.014 \\
\hline Number of company letters & $-0.150^{* * *}$ & $(0.009)$ & $-0.102^{* *}$ & $(0.052)$ & -0.012 \\
\hline Intercept & -0.014 & $(0.364)$ & $-2.706^{*}$ & $(1.996)$ & -0.315 \\
\hline Total number of observations & 261 & & 261 & & \\
\hline Adjusted $\mathrm{R}^{2}$ & 0.438 & Rho-squ & $=0.469$ & & \\
\hline F & 5.807 & 2(Log-lik & ood) $=167 .($ & & \\
\hline
\end{tabular}

*Statistically significant at the .10 level; **at the .05 level; ***at the .01 level (one-tailed tests). 
Table 4. Breakdown of $\mathrm{R}^{2}$ and

F Tests for Portions of the Model.

(Rho-Squared and Log-likelihood

Ratios Are Included for the Logit Equation)

\begin{tabular}{|c|c|c|c|c|}
\hline \multirow[b]{2}{*}{ Variable Categories } & \multicolumn{2}{|c|}{$\begin{array}{c}\text { Weighted Least } \\
\text { Squares Log } \\
\text { (\% Union } \\
\text { Vote/\% } \\
\text { No Vote) }\end{array}$} & \multicolumn{2}{|c|}{$\begin{array}{c}\text { Logit } \\
\text { Win-Lose }\end{array}$} \\
\hline & $R^{2}$ & $F$ & $\mathrm{RHO}^{2}$ & $L L R$ \\
\hline Union Tactics & 0.276 & 9.927 & 0.169 & 60.163 \\
\hline Individual Unions & 0.137 & 7.698 & 0.037 & $13.347^{* *}$ \\
\hline $\begin{array}{l}\text { All Contextual } \\
\text { Factors } \\
\text { Election } \\
\text { Background }\end{array}$ & 0.241 & 6.425 & 0.187 & 66.410 \\
\hline $\begin{array}{l}\text { Election } \\
\text { Environment }\end{array}$ & 0.123 & 12.873 & 0.008 & 25.838 \\
\hline $\begin{array}{l}\text { Company } \\
\text { Characteristics } \\
\text { Unit } \\
\text { Demographics }\end{array}$ & 0.135 & 7.607 & 0.035 & $12.628 * *$ \\
\hline $\begin{array}{l}\text { Organizer } \\
\text { Background }\end{array}$ & 0.162 & 9.200 & 0.055 & 19.619 \\
\hline Management Tactics & 0.155 & 6.823 & 0.057 & $20.229 * *$ \\
\hline
\end{tabular}

Significance levels of $\mathrm{p}$ values for $\mathrm{F}$ tests and $\mathrm{Log}$ likelihood Ratios: *.10; **.05; ***.01.

characteristics, and bargaining unit demographics.

\section{Results for Union Variables}

The descriptive statistics suggest that individual union tactics play an important role in determining election outcomes. As shown in Table 2, the components of a "rank-and-file intensive strategy" are associated with union win rates that are $12-26 \%$ higher than union win rates in campaigns that do not employ that strategy. Union win rates are highest in units where the union used campaign tactics such as representative committees $(62 \%$, versus $36 \%$ where there was not a representative committee), where $50 \%$ or more of the unit was housecalled $(61 \%$, versus $35 \%)$, where there was a bargaining committee before the election $(64 \%$, versus $39 \%)$, and where the union used new issues ( $56 \%$, versus $37 \%$ ). Win rates are also higher in elections where rank-and-file volunteers did housecalls (52\%, versus $40 \%$ ) and the union used solidarity days (53\%, versus $41 \%)$.

As shown in Table 3, the coefficients are positive and statistically significant at a level of .05 or better in one or both of the equations for eight out of the ten union campaign tactic variables: representative committee, percent cards, $50 \%$ or more housecalled, number of small group meetings, solidarity days, percent of the unit surveyed, bargaining committee chosen before the election, and focus on new issues. There are also negative and statistically significant results for the number of union letters variable.

In addition, variables measuring some elements that were present in only a small number of campaigns, such as rank-andfile volunteers, exhibited positive and statistically significant results when included in a reduced model that excluded the five union control variables as well as five other variables-manufacturing sector, whether the organizer has 1-5 years' rank-and-file experience, whether the organizer has a college degree, whether the organizer's parents are middle-class, and whether the employer used a consultant-that were hypothesized and found to be of limited importance to the certification election process. Excluding variables from the estimated equations did not change the sign of any of the statistically significant variables, but it did bring to a statistically significant level, or increase the statistical significance of, several key variables that had low sample frequency rates, including the variables for whether $50 \%$ or more of the unit was housecalled and whether rank-and-file volunteers did housecalls.

In the estimated logit equation, the partial derivatives of 136 for bargaining committee before the election, .141 for solidarity days, and 146 for the use of new issues by the union suggest that holding all other variables constant, the probability of the union winning the election increased $14 \%$ when the union used solidarity days or established the bargaining committee before 
the election and $15 \%$ when it focused on new issues. The partial derivatives of .079 for $50 \%$ or more of the unit housecalled and .064 for housecalls by rank-and-file volunteers suggest a $6-8 \%$ increase in the probability of winning the election where either of these tactics was used by the union. For every additional $10 \%$ of the bargaining unit surveyed one-on-one regarding what they wanted in the first contract, the estimated partial derivative of .001 suggests that the probability of winning the election increased by $1 \% .^{\prime \prime}$

The positive and statistically significant coefficients on the rank-and-file intensive tactic variables, together with the negative and statistically significant coefficients on the number of union letters variable, confirm the hypothesis that unions are more likely to win certification elections when they run campaigns using a rank-and-file intensive organizing strategy, including a reliance on person-to-person contact; an emphasis on union democracy and representative participation; the building for the

\footnotetext{
"Standardized coefficients are used in the WLS model because it is difficult to interpret the individual effects of the independent variables on the proportion of votes received by the union in an equation in which the dependent variable, a log odds ratio, is based on a non-linear transformation. However, the standardized coefficients do permit us to compare the relatively strong effects of the union tactic variables to the influence of the other variables in the model. In order to estimate the independent effects of union tactic variables on percent union vote, I also tested the model using Ordinary Least Squares (OLS). The OLS results are consistent with the logit and WLS results and suggest that controlling for the effect of other variables, the percent union vote would increase $6 \%$ in units with a rank-and-file organizing committee representative of the different interest groups in the bargaining unit, $10 \%$ in units where solidarity days were used, $3 \%$ in units where the bargaining committee was established before the election, and $8 \%$ in campaigns where the union focused on dignity and justice rather than bread-and-butter issues. Given that in more than $11 \%$ of the campaigns in the sample the union lost the election by a margin of $5 \%$ or less, these results suggest that if unions began to use all or most of these rank-and-file intensive campaign tactics, they could significantly improve their election win rates.
}

first contract during the organizing drive; the use of escalating pressure tactics; and an emphasis on dignity, justice, and fairness rather than solely bread-and-butter issues.

With the exception of the UFCW, all of the individual union variables exhibited their hypothesized sign in both equations and were statistically significant at a level of .10 or better in at least one equation. The strong results for the IBT variable demonstrate that the deficiencies of the Teamster election campaigns were not captured well by the union tactic variables. The weaker results for the other union control variables may arise because the organizing behavior of these unions is captured well by the union tactic variables. ${ }^{12}$ Yet the fact that four out of the five union variables have statistically significant coefficients in at least one of the estimated equations is consistent with the hypothesis that the overall "organizing culture" of the union, independent of union tactics, plays a role in determining the outcome of certification elections.

\section{Control Variables}

All but three of the 26 control variables had estimated coefficients with the hypothesized sign in both equations, and the estimated coefficients on 20 of the 26 variables were statistically significant at a level of .05 or better in at least one of the equations.

As other studies have found, this analysis suggests that the strongest contextual variables are the employer characteristics and bargaining unit demographic variables, which refer specifically to the unit being organized. The probability of the union winning the election declined by $11 \%$ in profitable companies and $22 \%$ in companies with some kind of participation pro-

\footnotetext{
${ }^{12}$ The positive (though not significant) results for the UFCW variable might be explained by the fact that the UFCW campaigns in the sample included a much higher percentage of wins than are found in the UFCW election population as a whole, and therefore may not be representative of the UFCW organizing record.
} 
gram in effect before the union drive. The probability of winning an election increased by $9 \%$ in low-wage units and in units with a majority of women, and improved by $3 \%$ for every 10 percentage point increase in the unit's minority representation. Unions also did better in workplaces where other units were organized, with the probability of winning the election increasing by $9 \%$ in those units.

Also consistent with the results of other studies is my finding that unions did particularly poorly in campaigns where the board or courts made unit changes after the election petition was filed, with the probability of winning the election declining by $15 \%$ in those units. As predicted, win rates also declined dramatically as unit size increased, with the union's probability of winning the election decreasing by $7 \%$ for every 10 additional voters added to the unit.

In contrast to these firm-specific contextual variables, the broader environmental variables such as unemployment and union density exhibited much weaker effects on both union vote and election outcome.

The results for the management tactic variables corroborate earlier studies showing the important influence of employer tactics on the percent union vote or election outcome. More than $75 \%$ of the employers in the sample engaged in active anti-union campaigns including some combination of discharges, captive audience meetings, supervisor one-on-one meetings with individual employees, wage increases, promises of improvements in wages, hours, or working conditions, promotions of union leaders, anti-union committees, small group meetings, letters, and leaflets. The estimated coefficients on all of these management tactic variables had a negative sign as hypothesized, and with the exception of the consultant and discharge variables, all of the management tactics variables were statistically significant in at least one of the equations. ${ }^{13}$

\footnotetext{
${ }^{13}$ For a more detailed discussion of the management tactics findings in this study and their implications for labor law reform, see Bronfenbrenner (1994).
}

As a group, the organizer background variables played a much less important role in determining union election success than did most of the other elements of the certification election model. This demonstrates that organizer training and philosophy, variables captured by the union tactic and individual union variables, play a more important role in determining election outcome than do the traits of the individual organizers.

The estimated coefficients on the international organizer variable show that the probability of the union winning the election increased by close to $20 \%$ in units where the organizer was on the international union's staff. The international organizer variable may be a proxy for organizer training and experience, and for the commitment of international resources. ${ }^{14}$

The small and statistically insignificant coefficients on the organizer female and minority variables may be due to the extremely small number of female and minority organizers in the sample $(12 \%$ women, $15 \%$ minority). Alternatively, it also may be due to the correlation between union tactics and the union propensity to hire female and minority organizers. That is, female and minority organizers may not be inherently better organizers than white male organizers, but rather the unions that are willing to hire female and minority organizers may be more likely to run rankand-file intensive campaigns. When the estimated model is reduced to 31 variables, however, the female minority lead organizer variable does become statistically significant at a level of .10 in both the WLS and the logit equations. Thus female and minority organizers not only are a proxy for

\footnotetext{
${ }^{14}$ The mixed results for the international organizer variable in the WLS equation suggest that by separating out international organizers we may not be accounting for unions such as ACTWU, which has a strong regional organizing structure, or the USWA, where organizers are on the international union's staff, but resources and power are concentrated at the regional level. Thus the variable may not consistently act as a proxy for organizer training and the commitment of resources across all unions.
} 
unions that run more aggressive campaigns, but they also may have had to work much harder and be much better organizers than their white male counterparts in order to prove themselves to their fellow staff and to the leaders of their unions.

\section{Conclusion and Implications}

This study demonstrates the value of moving beyond the narrow database of the NLRB to obtain data on bargaining unit demographics, employer and union characteristics, organizer and negotiator background, union tactics, and employer tactics beyond those on which charges were filed. In my analysis, the union tactic variables, both individually and as a group, are important determinants of union organizing success. This result suggests that many unions could improve their organizing success if they adopted a rank-and-file organizing strategy.

For most unions, that would involve a dramatic change in their organizing practice. All of the rank-and-file organizing tactics investigated in this study were used by less than a third of the campaigns in the sample. If all the organizers had employed elements of rank-and-file intensive campaigns such as representative committees, housecalls, rank-and-file volunteers, building for the first contract, solidarity days, and a focus on new issues, the percentage of elections won by unions, including those held in large units, would have been significantly higher.

If more unions begin to frequently use a rank-and-file intensive organizing strategy, the implications for the labor movement may go well beyond increasing union certification election win rates; for if significant numbers of workers join the labor movement through campaigns using these strategies and tactics, the face and very nature of the U.S. labor movement could change. Not only would unions be organizing more women and people of color, but regardless of background or industry, union members coming out of a successful rank-and-file intensive campaign are likely to hold the union to higher standards regarding both internal union democracy and union performance than are union members who were organized through more traditional election campaigns.

What these findings make clear is that union organizing strategy and tactics matter a great deal in determining certification election outcomes. In the coming years, as the new leadership of the AFL-CIO commits millions of dollars in staff and resources toward the running of aggressive NLRB, community-based, and industrybased campaigns, industrial relations research can play an important role in critically evaluating the impact and effectiveness of these organizing initiatives. 


\section{REFERENCES}

AFL-CIO . 1989. AFL-CIO Organizing Survey: 19861987 NLRB Elections. Washington, D.C.: AFL-CIO.

Aldrich, John, and Forest D. Nelson. 1984. Linear Probability, Logit, and Probit Models. Sage University Paper Series on Quantitative Applications in the Social Sciences, 45. Beverly Hills and London: Sage.

BNA Plus. 1989. NLRB Election Data, 1986-89 (Customized Report). Washington, D.C.: Bureau of National Affairs.

Bronfenbrenner, Kate. 1993. "Seeds of Resurgence: Successful Union Strategies for Winning Certification Elections and First Contracts in the 1980's and Beyond," Diss., Cornell University.

1994. "Employer Behavior in Certification Elections and First Contracts: Implications for Labor Law Reform." In Sheldon Friedman, Richard Hurd, Rudy Oswald, and Ronald Seeber, eds., Restoring the Promise of American Labor Law. Ithaca, N.Y.: ILR Press, pp. 75-89.

Bronfenbrenner, Kate, and Tom Juravich. 1995a. "The Impact of Employer Opposition on Union Certification Win Rates: A Private/Public Comparison." Economic Policy Institute Working Paper No. 113.

1995b. Union Organizing in the Public Sector: An Analysis of State and Local Elections, Ithaca, New York: ILR Press.

1995c. "Union Tactics Matter: The Impact of Union Tactics on Certification Elections, First Contracts and Membership Rates." Institute for the Study of Labor Organizations Working Paper.

Bureau of Labor Statistics (BL.S). 1986-1988. Employment and Unemployment. Washington, D.C.: GPO.

Cooke, William N. 1983. "Determinants of the Outcomes of Union Certification Elections." Industrial and Labor Relations Review, Vol. 36, No. 3 (April), pp. 402-13.

Curme, Michael A., Barry T. Hirsch, and David A. Macpherson. 1990. "Union Membership and Contract Coverage in the United States, 1983-1988," Industrial and L.abor Relations Review, Vol. 44, No. 1 (October), pp. 5-33.

Fetonte, Danny, and Larry Braden, 1990. "Showdown at Nacogdoches: The CWA in Texas." Labor Research Review, Vol. 15, No. 1, pp. 24-35.

Fiorito, Jack, and Charles Greer. 1982. "Determinants of U.S. Unionism: Past Research and Future
Needs." Industrial Relations, Vol. 21, No. 1 pp. 1-32. Green, James, and Chris Tilly, 1987. "Service Unionism. Directions for Organizing." Labor Law Journal, Vol. 38, No. 8 (August), pp. 486-95.

Howley, John. 1990. "Justice for Janitors: The Challenge of Organizing in Contract Services," Labor Research Review, Vol. 15, pp. 60-71.

Hurd, Richard. 1989. "Learning from Clerical Unions: Two Cases of Organizing Success." Labor Studies Journal, Vol. 14, pp. 30-51.

Hurd, Richard, and Adrienne McElwain. 1988. "Organizing Clerical Workers: Determinants of Success." Industrial and Labor Relations Review, Vol. 41, No. 3 (April), pp. 350-73.

Ladd-Taylor, Molly. 1985. "Women Workers and the Yale Strike." Feminist Studies, Vol. 11, No. 3, pp. 465489.

Lawler, John J. 1990. Unionization and Deunionization. Columbia, S.C.: University of South Carolina Press.

Lynn, Monty L., and Jozell Brister. 1989. "Trends in Union Organizing: Issues and Tactics." Industrial Relations, Vol. 28, No. 1, pp. 104-13.

Maddala, G. S. 1983. Limited-Dependent and Qualitative Variables in Econometrics. Cambridge: Cambridge University Press.

Maranto, Cheryl L.., and Jack Fiorito. 1987. "The Effect of Union Characteristics on the Outcome of NLRB Certification Elections." Industrial and Labor Relations Review, Vol. 40, No. 2 (January), pp. 22540.

Midwest Center for Labor Research. 1992. "Editor's Introduction." Labor Research Review, Vol. 18, No. 2, p. iv.

Reed, Thomas F. 1989. "Do Organizers Matter? Individual Characteristics and Representation Election Outcomes." Industrial and Labor Relations Review, Vol. 43, No. 1 (October), pp. 103-19.

Sweeney, John, Richard Trumka, and Linda ChavezThompson. 1995. "A New Voice for American Workers: Rebuilding the American Movemen-A Summary of Proposals from the Unions Supporting John J. Sweeney, Richard Trumka, and Linda ChavezThompson." Washington, D.C.: New Voice for American Workers.

Wheeler, Hoyt N., and John McClendon. 1991. "The Individual Decision to Unionize." In George Strauss, Daniel Gallagher, and Jack Fiorito, eds., The State of the Unions. Madison: IRRA, pp. 47-84. 
Copyright of Industrial \& Labor Relations Review is the property of Cornell University and its content may not be copied or emailed to multiple sites or posted to a listserv without the copyright holder's express written permission. However, users may print, download, or email articles for individual use. 